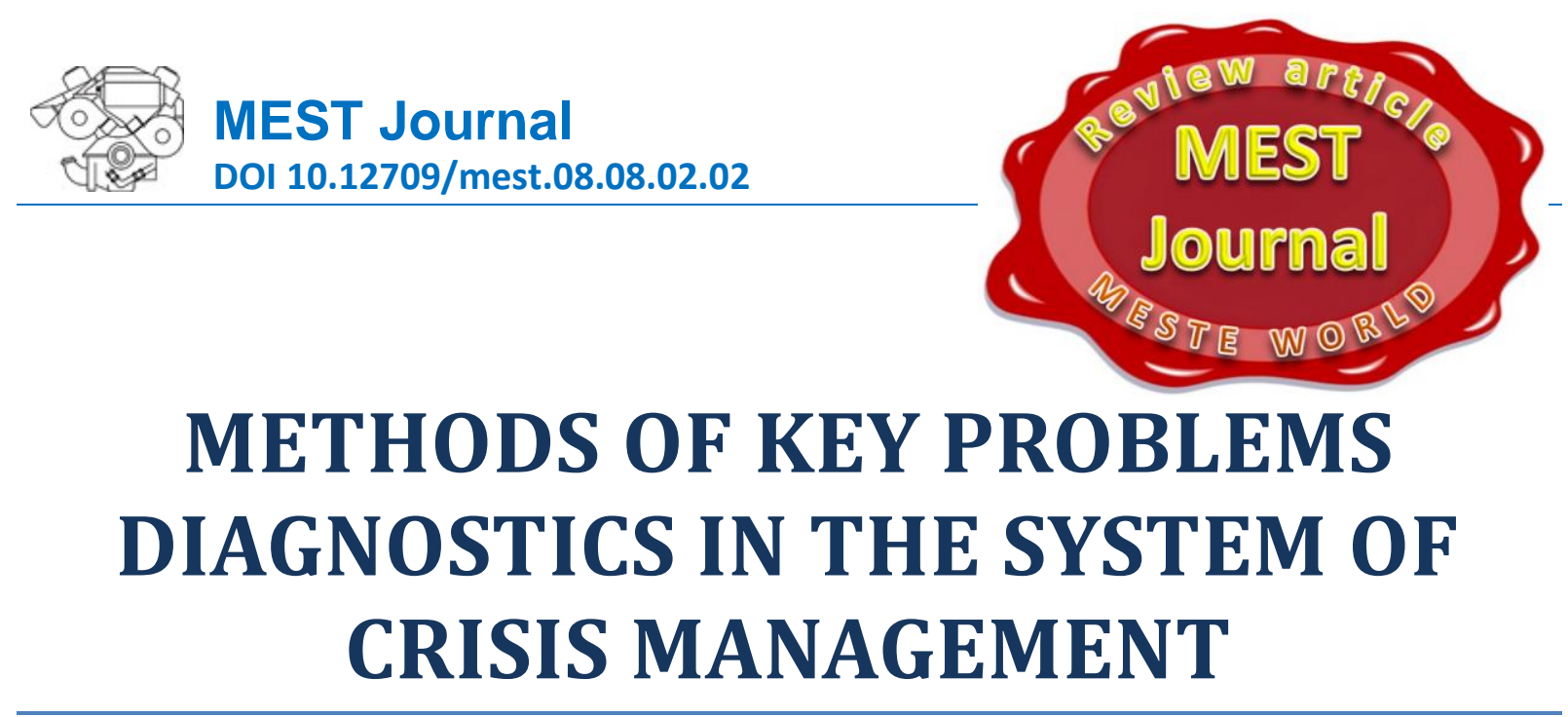

\title{
Konon Bagrii
}

Chernivtsi Institute of Trade and Economics of Kyiv National University of Trade and Economics, Chernivtsi, Ukraine

\section{Alla Romanchuk}

Chernivtsi Institute of Trade and Economics of Kyiv National University of Trade and Economics, Chernivtsi, Ukraine

\section{Mustetsa Iryna}

Chernivtsi Institute of Trade and Economics of Kyiv National University of Trade and Economics, Chernivtsi, Ukraine

\section{CMESTE}

JEL Category: B41, M10

\begin{abstract}
The content of anti-crisis management, based on the opinions of leading scientists, is revealed in a scientific article. Own interpretation of this concept, which covers all the advantages of the most famous statements of leading scientists has been made. Practical aspects of crisis management with an orientation to its basic sections and anti-crisis programs are identified. Understanding these sections allows managers to generate timely measures that will meet the level of the crisis of the enterprise. Emphasis is placed on crisis forecasting and bankruptcy methods. To gain a better understanding of the methodological support of crisis management, its basic methods and methods have been systematized and classified. The general division of classical techniques involves the selection of techniques using multifactorial models and evaluation using estimates. According to the status of regulation, it is advisable to group the methods of crisis diagnosis into mandatory (state) and recommended (scientific). The most popular multifactorial models of crisis management analysis are identified with their advantages and disadvantages. All considered models are adapted for enterprises of economically developed countries and do not consider the peculiarities of the functioning of economic entities in Ukraine. The article defines the directions of further improvement of methodological support of crisis management at domestic enterprises, among which the strengthening of the information base for analysis, clearer

Address of the corresponding author: Konon Bagrii 奉kononbagriy@gmail.com

formulation of the goals of analysis, the unification of the assessment of the financial condition of enterprises of all forms of ownership and organizational and legal forms of management are
\end{abstract}


highlighted. The authors define further directions of scientific researches in the sphere of crisis management of the enterprise under difficult market conditions.

Keywords: crisis management, crisis, bankruptcy, diagnostics, analysis, management methods, problems, anticrisis, business systems

\section{INTRODUCTION}

Difficult market conditions, severe competition, high levels of uncertainty significantly complicate the functioning of most businesses, resulting in huge crises, and bankruptcies. Often the reason for this situation for business entities is the lack of management skills, which are not able to timely identify a crisis and adequately respond to it, and take effective measures. That is why it is important today to create a holistic system of tools that will allow managers to effectively eliminate troublesome phenomena and prevent potential bankruptcy.

In the scientific community, the issue of crisis management is widely studied and discussed. This is evidenced by the huge number of works of famous scientists, among which it is worth noting: Lihonenko, L. (2005), Hradov, A., \& Kuzyn, B. (1996), L. Sytnyk (2000), L. Skibitka (Skibits'ka, L., Matvieiev, V., Schelkunov, V., \& Podrieza, S., 2014), Hriaznovoj, A.(1999), V. Vasylenko, V. (2003), Minaev, E., \& Panahushyn, V. (1998), Afanas'ev, H. (1998), Patterson, B., (1993), Madsen, K., \& Platz, N. (2005), Green, P., (1992) and others. But the dynamic environment in which businesses operate is constantly demanding the consideration of new factors and conditions, revision of existing theoretical foundations of crisis management, improvement of existing methods and approaches for timely identification and elimination of problem situations and places in the activity of the enterprise.

The main purpose of the research is to consider the existing theoretical and methodological foundations of crisis management and to form a system of methods of forecasting and identifying crises, adapted to the modern realities of the economic life of the enterprise, with further development of effective measures.

\section{THEORETICAL BASIS OF ANTI- CRISIS MANAGEMENT}

The prerequisite for the emergence of crisis management is due to simple and logical reasons, including the emergence of a wide range of diverse problems faced by enterprises in the course of management, and the development of management as a science and a separate management function.

The term crisis management or crisis management is a fairly new term that entered the domestic scientific space in the mid-1990s. As a rule, the substantive content of this economic definition encompasses the practical application of a system of techniques and methods in overcoming a crisis for any business unit.

However, to understand in more detail this area of practice, it is necessary to trace the basic context, which was embedded in the concept of "crisis management" in Western countries, which are rightfully its founders.

All Western scholars trying to uncover the essence of anti-crisis management are conditionally divided into several groups:

1. view it as measures aimed at crisis prevention.

2. understand the directions and methods that help the business structure to overcome the crisis.

3. integrate the ideas of the previous two groups, revealing crisis management as a direction of management activities aimed at preventing, eliminating, and responding to crisis effects and maximizing and effectively eliminating their consequences.

The results of a detailed and critical analysis of the statements of leading Western economic and domestic scientists are summarized in Table 1. 
Table1 Disclosure of the term "crisis management" by leading scientists

\begin{tabular}{|c|c|c|}
\hline Author, source & Definition of crisis management & Comments \\
\hline $\begin{array}{c}\text { Mitroff, I., } \\
1994\end{array}$ & $\begin{array}{l}\text { A consistent interdependent } \\
\text { assessment of the various types of } \\
\text { crises and forces that may pose a threat } \\
\text { to the organization }\end{array}$ & $\begin{array}{l}\text { Such determination is oriented only to } \\
\text { the assessment of existing crisis } \\
\text { phenomena without their possible } \\
\text { prediction or development of } \\
\text { measures for their elimination }\end{array}$ \\
\hline $\begin{array}{c}\text { Humphreys, C., } \\
1992\end{array}$ & $\begin{array}{l}\text { The direction of management aimed at } \\
\text { minimizing losses and other negative } \\
\text { results with the further support of trust in } \\
\text { the company, its management, and } \\
\text { corporate image among employees, } \\
\text { customers, shareholders, and the } \\
\text { general environment }\end{array}$ & $\begin{array}{l}\text { The main focus is on finding ways out } \\
\text { of the crisis and maintaining a good } \\
\text { reputation. The downside is no } \\
\text { mention of evaluating the causes of } \\
\text { crisis phenomena to further prevent } \\
\text { them }\end{array}$ \\
\hline $\begin{array}{c}\text { Head, G., } \\
1990\end{array}$ & $\begin{array}{l}\text { Crisis management is designed to } \\
\text { provide a coordinated, effective } \\
\text { response to the crisis through planning, } \\
\text { management and control of the } \\
\text { organization and its assets immediately } \\
\text { before, during, and after the organization } \\
\text { has suffered losses as a result of the } \\
\text { crisis to conserve the resources it needs } \\
\text { to the fullest possible recovery of the } \\
\text { pre-crisis level in the future }\end{array}$ & $\begin{array}{l}\text { Such a context of crisis management } \\
\text { most characterizes it, paying attention } \\
\text { to which management functions are } \\
\text { involved, time of their use and } \\
\text { targeting. On the positive side, the } \\
\text { author focuses on not only getting out } \\
\text { of the crisis but also preventing it, the } \\
\text { direction of action at the time of being } \\
\text { in crisis. }\end{array}$ \\
\hline $\begin{array}{c}\text { Korotkov, E., \& } \\
\text { Beliaev, A., \& } \\
\text { Valovoj, D., } \\
2000\end{array}$ & $\begin{array}{l}\text { Management, which is predetermined in } \\
\text { some way to predict the threat of a crisis, } \\
\text { analyze its symptoms, measures to } \\
\text { reduce the negative effects of the crisis } \\
\text { and use its factors for the next } \\
\text { sustainable development of the } \\
\text { organization }\end{array}$ & \multirow{2}{*}{$\begin{array}{l}\text { The authors define this concept as a } \\
\text { permanent management style, } \\
\text { providing a daily assessment of all } \\
\text { factors that may lead to a crisis, as well } \\
\text { as situations in which businesses are } \\
\text { located and bear signs of problematic } \\
\text { phenomena. }\end{array}$} \\
\hline $\begin{array}{c}\text { Vasylenko, V., } \\
2003\end{array}$ & $\begin{array}{l}\text { Management, which foresees the } \\
\text { danger of the crisis, analysis of its } \\
\text { symptoms, measures to reduce the } \\
\text { negative effects of the crisis and use its } \\
\text { factors for positive development }\end{array}$ & \\
\hline $\begin{array}{l}\text { Skibitska, L., \& } \\
\text { Matvieiev, V., \& } \\
\text { Schelkunov, V., } \\
\text { \& Podrieza S., } \\
2014\end{array}$ & $\begin{array}{l}\text { The main goal of anti-crisis management } \\
\text { is to develop and prioritize measures } \\
\text { aimed at neutralizing the most } \\
\text { dangerous factors that lead to a crisis. }\end{array}$ & $\begin{array}{l}\text { Given disclosure of the term is focused } \\
\text { solely on the formulation of strategic } \\
\text { measures that should eliminate the } \\
\text { impact of the crisis factors, but the } \\
\text { assessment of the current situation } \\
\text { remains without attention. }\end{array}$ \\
\hline $\begin{array}{l}\text { Lihonenko, L., } \\
2005\end{array}$ & $\begin{array}{l}\text { Special, permanently organized } \\
\text { management, aimed at the most prompt } \\
\text { detection of signs of crisis and creation } \\
\text { of appropriate prerequisites for its timely } \\
\text { overcoming to ensure the restoration of } \\
\text { the viability of an individual enterprise, } \\
\text { preventing the situation of its bankruptcy }\end{array}$ & $\begin{array}{l}\text { The interpretation states the day-to- } \\
\text { day need to implement such } \\
\text { specialized management to prevent } \\
\text { bankruptcy and properly maintain the } \\
\text { viability of the enterprise. A sufficient } \\
\text { and inclusive definition }\end{array}$ \\
\hline
\end{tabular}




\begin{tabular}{|c|c|c|}
\hline Author, source & Definition of crisis management & Comments \\
\hline $\begin{array}{c}\text { Hradov, A., \& } \\
\text { Kuzyn, B., } \\
1996\end{array}$ & $\begin{array}{l}\text { Set of consecutive general measures: } \\
\text { analysis of the state of macro- and } \\
\text { microenvironment, selection of the } \\
\text { appropriate mission of the enterprise; } \\
\text { study of the economic mechanism of } \\
\text { emergence of crises and creation of a } \\
\text { system of scanning of the external and } \\
\text { internal environment of the enterprise for } \\
\text { early detection of weak signals about the } \\
\text { crisis; strategic control of the enterprise } \\
\text { activity and development of a strategy } \\
\text { for preventing its insolvency; prompt } \\
\text { assessment and analysis of the financial } \\
\text { state of the enterprise, identifying the } \\
\text { possibility of insolvency (bankruptcy); } \\
\text { developing a crisis response system to } \\
\text { deal with the crisis; constant accounting } \\
\text { of risk of business activity and } \\
\text { development of measures for its } \\
\text { reduction }\end{array}$ & $\begin{array}{l}\text { The author expands the context of the } \\
\text { concept of "crisis management" as a } \\
\text { step-by-step algorithm of actions and } \\
\text { tools that prevent bankruptcy and } \\
\text { avoid the factors that trigger crisis } \\
\text { phenomena. }\end{array}$ \\
\hline $\begin{array}{l}\text { Sytnyk, L., } \\
2000\end{array}$ & $\begin{array}{l}\text { Management system aimed at solving } \\
\text { problems of intensive development of } \\
\text { the enterprise by mobilizing and } \\
\text { intensifying all resources as opposed to } \\
\text { extensive development }\end{array}$ & $\begin{array}{l}\text { The peculiarity of such a statement is } \\
\text { the disclosure of the content of anti- } \\
\text { crisis measures. According to the } \\
\text { author, to prevent bankruptcy is to } \\
\text { "mobilize and intensify all resources as } \\
\text { opposed to extensive enterprise } \\
\text { development" }\end{array}$ \\
\hline $\begin{array}{c}\text { Minaev, E., \& } \\
\text { Panahushyn, V., } \\
1998\end{array}$ & $\begin{array}{l}\text { Not only management focused on } \\
\text { withdrawal of the enterprise from the } \\
\text { state of crisis, but also management, } \\
\text { which should anticipate and prevent the } \\
\text { insolvency of the enterprise in advance } \\
\text { following the strategic program of } \\
\text { enhancing competitive advantages and } \\
\text { financial recovery }\end{array}$ & $\begin{array}{l}\text { Positive in this statement is not only } \\
\text { the retrospective aspect of anti-crisis } \\
\text { management but also the orientation } \\
\text { on the prediction and prevention of } \\
\text { problem situations in the activity of the } \\
\text { enterprise. }\end{array}$ \\
\hline $\begin{array}{l}\text { Cherniavs'kyj, } \\
\text { A., } 2006\end{array}$ & $\begin{array}{l}\text { Management capable of preventing or } \\
\text { mitigating crises in production and } \\
\text { economic activity, as well as maintaining } \\
\text { the functioning of the enterprise in the } \\
\text { survival mode in times of crisis and } \\
\text { leaving the crisis with minimal losses }\end{array}$ & $\begin{array}{l}\text { The definition is threefold: } \\
\text { a) Crisis prevention. } \\
\text { b) Survival of the enterprise in crisis. } \\
\text { c) Exit from the crisis with minimal } \\
\text { losses. }\end{array}$ \\
\hline
\end{tabular}

Based on all existing definitions it is possible to form the most complete and comprehensive one. Crisis management is an enterprise management system with a complex, systematic nature and aimed at preventing or eliminating unfavorable business phenomena by using the full potential of modern management, developing, and the implementation of a special program at the enterprise. It is strategic and eliminates temporary difficulties, maintains and improves the market position of the enterprise in any way $s$ circumstances, mainly using its resources. 
3 PRACTICAL TOOLS OF CRISIS MANAGEMENT

A clear organization of crisis management requires an understanding of all theoretical and practical aspects. Today, in the scientific community, they are all organized into separate sections, namely: three classical sections (CM) and a special part - CA. However, if these sections are aimed at crisis management, then the section and its contents are slightly corrected, and the letter $\mathrm{A}$. supplements the abbreviation itself.

1. CP crisis planning

dedicated to work in a non-crisis situation - how to make a pre-crisis situation from a non-crisis situation, that is, to create absent objective conditions on which a crisis-fracture may occur.

\begin{tabular}{|c|c|}
\hline ACP anticrisis planning - is dedicated to preventing the objective preconditions for crisis in a non-crisis situation. \\
\hline $\begin{array}{c}\text { Crisis management } \\
\text { program }\end{array}$
\end{tabular}$\rightarrow \begin{aligned} & \text { measures to move from non-crisis to pre-crisis. Blocking and elimination of objective conditions } \\
& \text { of crisis. }\end{aligned}$

2. CC crisis controlling

is used in the pre-crisis situation and is dedicated to how to put into practice the objective prerequisites for the crisis, that is,
"untwist" the pre-existing pre-conditions to such an extent that the pre-crisis situation ends in a crisis.
ACC anticrisis controlling - dedicated to preventing a crisis in the pre-crisis situation.
Crisis management
program
promotinguishing the already existing objective conditions for the crisis, preventing them from being
practical initiation of the crisis on the basis of completely ready preconditions, action immediately at the very moment of the crisis
3. CA crisis action

ACA anticrisis action - emergency countermeasures, neutralizing qualitative changes triggered by a crisis that has already begun.

\begin{tabular}{|c|c|}
\hline $\begin{array}{c}\text { Crisis management } \\
\text { program }\end{array}$ & $\begin{array}{l}\text { actually anti-crisis measures. Very decisive and harsh actions, neutralizing qualitative changes } \\
\text { of the crisis or prevent them. }\end{array}$ \\
\cline { 2 - 3 }
\end{tabular}

\section{CR crisis reaction}

refers to the post-crisis situation, when the crisis has already occurred, and it is necessary to fix its consequences as fully as possible, not to let them go away, to prevent the situation from gradually returning to its former, pre-crisis state.

ACR anticrisis reaction - dedicated to how to minimize the effects of a crisis that has already happened, and even better smoothly repay them and return to their previous, pre-crisis state.

\begin{tabular}{|c|c|}
$\begin{array}{c}\text { Crisis management } \\
\text { program }\end{array}$ & $\rightarrow \begin{array}{l}\text { minimizing the effects of crisis if despite all previous measures, it has nevertheless taken place. } \\
\text { Also becomes valid if all previous parts had no effect. }\end{array}$ \\
\hline
\end{tabular}

Fig. 1 Sections and programs of crisis management (developed by the authors)

A special crisis management program is formed for each individual situation. The description of such parts of anti-crisis management is systematized in Fig. 1.

The choice of a particular system of measures depends on the situation in which the enterprise is located. In practice, there are events where no decisive action is required, but only to prevent the adverse effects of a changing external environment. An example would be a situation where a business is going well and management should only support the positive trends.

\section{METHODS OF FORECASTING PROBLEM SITUATION}

Crisis management should be oriented not only to the assessment of the pre-existing crisis but also to a great extent prevent the influence of factors that can lead to problems in the activity of an individual enterprise. Nowadays, scientists have 
differently defined areas of analysis aimed at diagnosing a crisis in an entity's activity or forecasting it in the near future. However, the most popular among them are: identification of problems that are negative consequences of enterprise management (Balashov, A., 2004); performance of targeted financial analysis (Green, P., 1992); assessment of the current situation according to the criteria of presence or absence of crisis (James, E., 2009); study of the goals of the enterprise and ways to achieve them (Afanas'ev, H., 1998).

In general, it should be noted that the diagnosis and forecasting of crisis at the enterprise is a set of economically sound methods and techniques of financial and economic analysis. When they are systematically applied at certain intervals (depending on the size, characteristics, type of activity, etc.) will allow identifying the crisis on time and evaluating potential functioning and development opportunities. Therefore, a special place in such a crisis management system is assigned to methodological support.

The current practice of crisis management has a wide arsenal of methods and techniques, which for their qualitative selection and application requires proper systematization (Fig. 2).

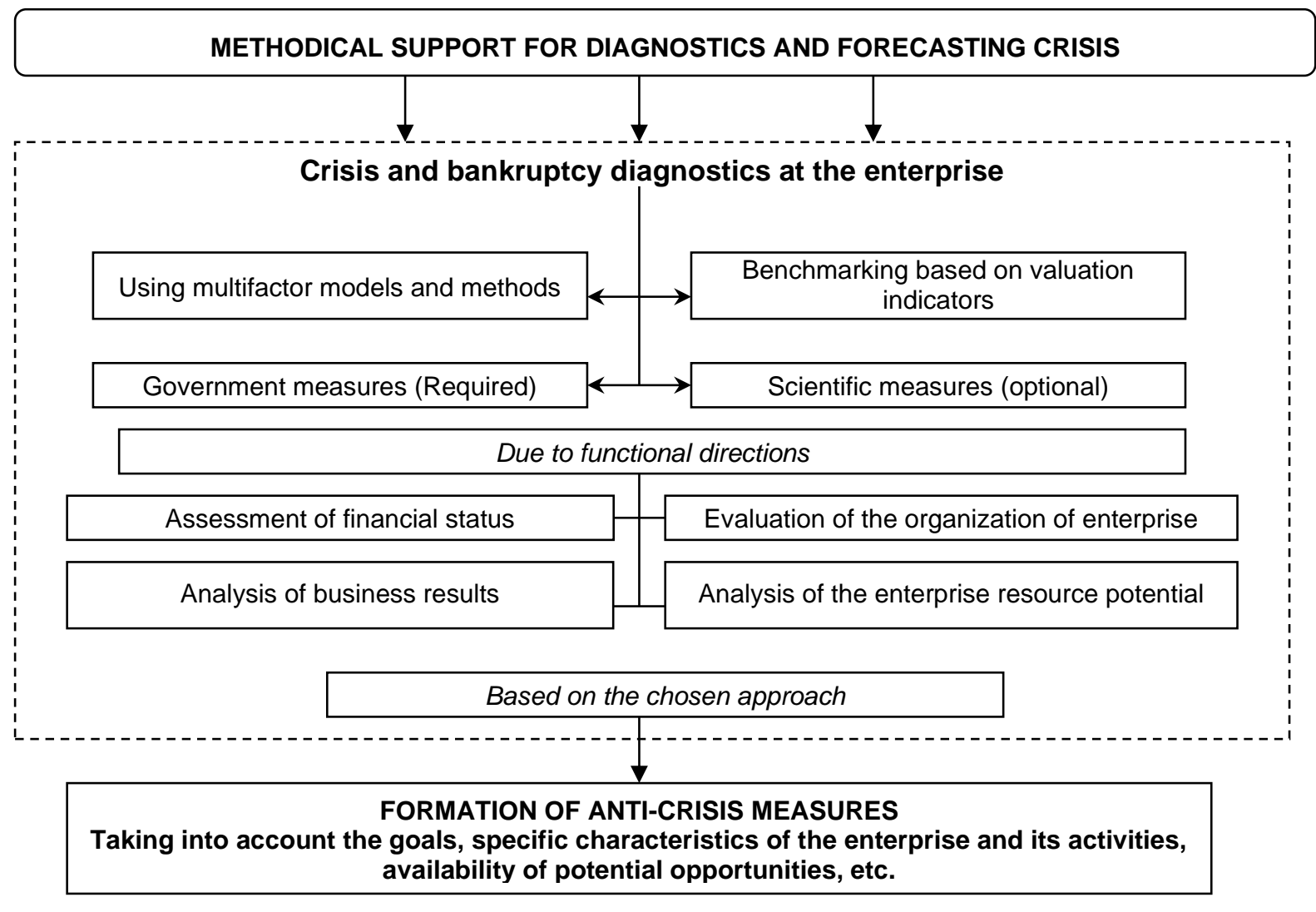

Fig. 2 Contents of methodological support of crisis and bankruptcy diagnostics and forecasting

Source: (developed by the authors)

All methods that formulate methodological support for crisis diagnostics have the same purpose - to provide the management of employees with the appropriate information, which will help to make sound and effective decisions that will help to form a satisfactory balance sheet structure and to create an adequate level of solvency of the enterprise.

It should be noted that for the best results of forecasting problem situations in the activity of the enterprise it is appropriate to apply a combined approach, which would simultaneously cover the assessment of both financial condition and results of management, resource potential, etc. This will summarize the impact of both the individual component of the activity and its entire complex on the possibility of a crisis and its subsequent course. The use of purely financial metrics significantly limits the overall understanding of the existing picture and does not identify the main causes of problems for an entity. 
Quite often, scientists identify the diagnosis of the solvency of the enterprise with the prediction of its bankruptcy. You can agree with this view since a protracted crisis can lead to a deterioration of the parameters of solvency and gradual bankruptcy.
Modern science has dozens of models that allow determining with certain accuracy the likelihood of a crisis. The most popular of them are considered in Fig. 3.

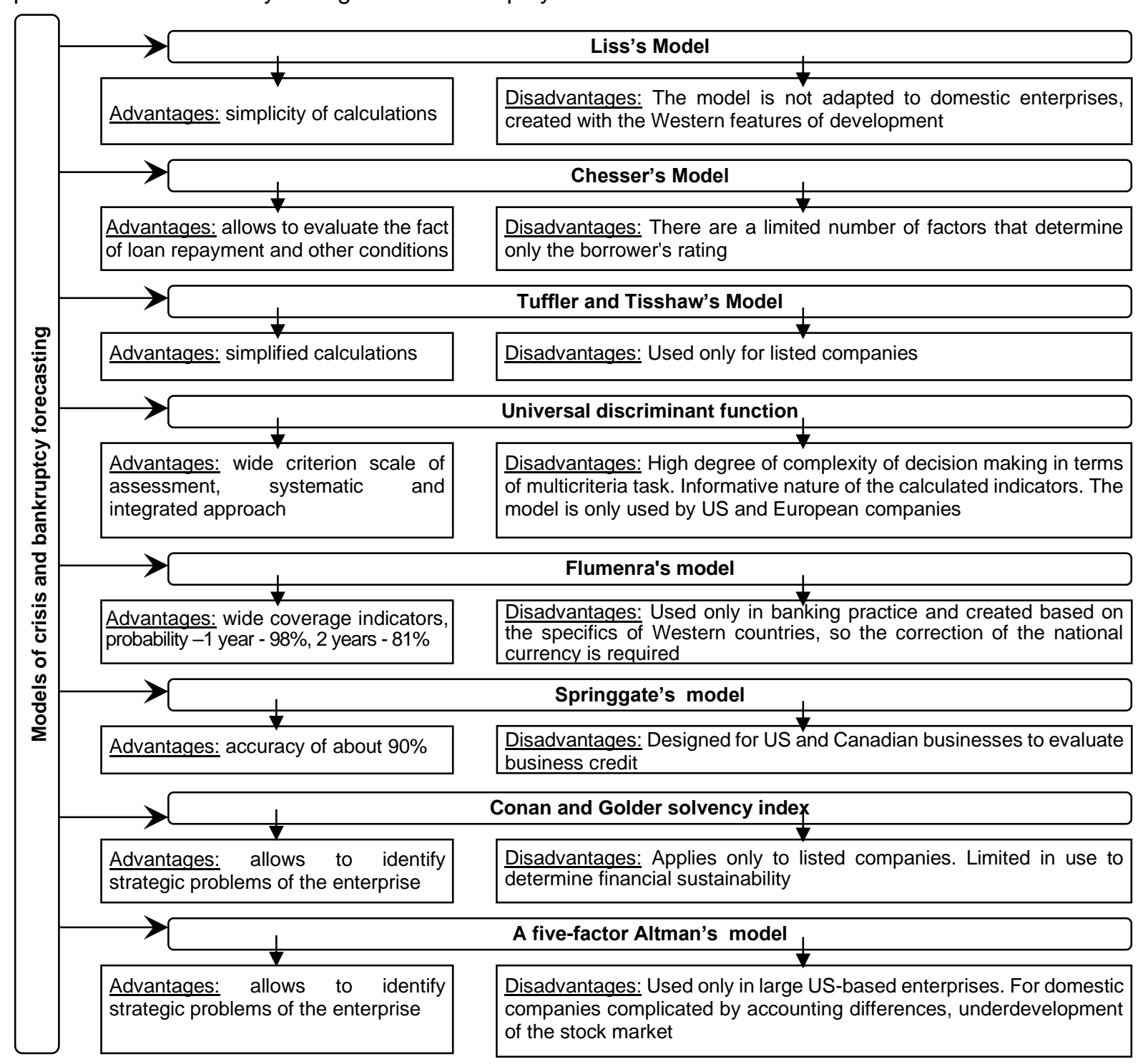

Fig. 3 Comparative characteristics of models of forecasting the crisis of the enterprise

Source: (developed by the authors)

Among the models presented in Fig. 3 it is difficult to distinguish the most versatile models. First of all, it has to do with adapting them to different conditions of functioning and development. If we talk about business units in the West, the models of economists Lis, Taffler, Tisshaw, etc., will be optimal for them, since they take into account the peculiarities of the legislative and legal field, state regulation, competition conditions inherent in the USA, Great Britain and more. For enterprises from less developed countries, the application of multifactor models has some difficulties, which is caused by the following factors:

a. instability and imperfection of the regulatory framework;

b. poor quality and informative content of the reporting documents;

c. biased statistics and their limited potential for bankruptcy.

That is why all the described models do not allow us to take into account the absolute majority of 
conditions of functioning of the domestic enterprise.

\section{CONCLUSIONS}

To summarize the above, we believe that Ukrainian financial analysts should develop their model, which would allow estimating the financial status and other parameters of the absence of crisis manifestations with full integration into its algorithm of national accounting standards and reporting, use different information sources that would reveal all industries in which businesses operate.

As possible directions of adaptation of existing models of crisis diagnostics at Ukrainian enterprises it is possible to distinguish:

a. provision of sufficient database for diagnostics both at the macro level and at meso and macro levels;

\section{WORKS CITED}

Afanas'ev, H. (1998). Antykrizisnoe upravlenie [Crisis management]. TsMG, Moscow, Russia, available at http://studentam.net/content/view/538/63/.

Balashov, A. (2004). Antykrizisnoe upravlenie [Crisis management]. GUP RPO SO RASHN, Novosybyrsk, Russia.

Cherniavs'kyj, A. (2006). Antykryzove upravlinnia pidpryiemstvom [Crisis management in enterprise]. MAUP, Kyiv, Ukraine

Green, P. (1992). Reputation Risk Management, Pitman/Finantsial Times, London, UK.

Head, G. (1990). Crisis Plans Ensure Companies' Future. Business Insurance, 24(22), p. 39.

Hradov, A., \& Kuzyn, B. (1996). Stratehyia i taktyka antykryzysnoho upravlenyia firmy [Strategy and tactics of firm's crisis management]. Spetsyal'naia lyteratura, Sent-Petersburg, Russia.

Hriaznovoj, A. (1999). Antykrizisnoe upravlenie [Crisis management]. EKMOS, Moscow, Russia.

Humphreys, C. (1992). Crisis Planning: Necessity, Not Luxury. Bank Marketing, 24(6), pp. 34-35.

James, E. (2009). Leadership as (un)usual: How to display competence in times of crisis. Available at : http://www.erikahayesjames.com (accessed 10 December 2019).

Korotkov, E., Beliaev, A., \& Valovoj, D. (2000). Antykrizisnoe upravlenie [Crisis management]. YNFRA-M, Moscow, Russia.

Lihonenko, L. (2005). Antykryzove upravlinnia pidpryiemstvom [Crisis management in enterprise], KNEU, Kyiv, Ukraine.

Madsen, K., \& Platz, N. (2005). Crisis Management in IT Projetsts. Aalborg University, Denmark, available at: http://www.itu.dk/iris29/IRIS29/5-3.pdf (accessed 10 December 2019).

Minaev, E., \& Panahushyn, V. (1998). Antykrizisnoe upravlenie [Crisis management]. PRYOR, Moscow, Russia. 
Mitroff, I. (1994). Crisis management and environmentalism. California Management Review, 36(2), pp. 101-113.

Patterson, B. (1993). Crises impact on reputation management. Public Relations Journal, 49(11), p. 48.

Skibits'ka, L., Matvieiev, V., Schelkunov, V., \& Podrieza S. (2014). Antykryzovyj menedzhment [Crisis management]. Tsentr uchbovoi literatury, Kyiv, Ukraine.

Sytnyk, L. (2000). Orhanizatsijno-ekonomichnyj mekhanizm antykryzovoho upravlinnia pidpryiemstvom [Organizational and economic mechanism of crisis management in enterprise]. IEP NAN Ukrainy, Donets'k, Ukraine.

Vasylenko, V. (2003). Antykryzove upravlinnia pidpryiemstvom [Crisis management in enterprise]. TsUL, Kyiv, Ukraine.

Received for publication: $\quad 17.01 .2020$

Revision received: $\quad 02.05 .2020$

Accepted for publication: $\quad 01.07 .2020$

\section{How to cite this article?}

Style - APA Sixth Edition:

Bagrii, K., Romanchuk, A., \& Iryna, M. (2020, July 15). Methods of key problems diagnostics in the system of crisis management. (Z. Cekerevac, Ed.) MEST Journal, 8(2), 9-17. doi:10.12709/mest.08.08.02.02

Style - Chicago Sixteenth Edition:

Bagrii, Konon, Alla Romanchuk, and Mustetsa Iryna. 2020. "Methods of key problems diagnostics in the system of crisis management." Edited by Zoran Cekerevac. MEST Journal (MESTE) 8 (2): 917. doi:10.12709/mest.08.08.02.02.

Style - GOST Name Sort:

Bagrii Konon, Romanchuk Alla and Iryna Mustetsa Methods of key problems diagnostics in the system of crisis management [Journal] // MEST Journal / ed. Cekerevac Zoran. - Belgrade - Toronto : MESTE, July 15, 2020. - 2 : Vol. 8. - pp. 9-17.

Style - Harvard Anglia:

Bagrii, K., Romanchuk, A. \& Iryna, M., 2020. Methods of key problems diagnostics in the system of crisis management. MEST Journal, 15 July, 8(2), pp. 9-17.

Style - ISO 690 Numerical Reference:

Methods of key problems diagnostics in the system of crisis management. Bagrii, Konon, Romanchuk, Alla and Iryna, Mustetsa. [ed.] Zoran Cekerevac. 2, Belgrade - Toronto : MESTE, July 15, 2020, MEST Journal, Vol. 8, pp. 9-17. 